\title{
Ownership structure and accountability: the case of the privatization of the Spanish tobacco monopoly, 1887-96
}

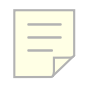

\author{
Marta Macías
}

\begin{abstract}
This paper analyses the case of the privatization of the Spanish tobacco monopoly, focusing on the period between 1887 and 1896, which corresponds to the first leasing contract between the state and the Spanish Tobacco Company and it is concerned with two different issues. First, it deals with the effects of privatization on accountability. The main question examined is whether public and private ownership entail different approaches to the way in which managers are accountable to owners, and the impact this issue had on corporate reporting. Second, it is concerned with exploring the determinants of accounting disclosure. Here, the basic issue is to understand the factors shaping changes in corporate reporting during the period of study.
\end{abstract}

Keywords: accounting history; corporate reporting; privatization; tobacco monopoly; Spain

\section{Introduction}

The development of financial reporting practices represents an area of growing interest among accounting scholars. External reporting has been traditionally assumed to arise as a consequence of the emergence of limited companies in the nineteenth century (e.g. Bryer, 1993; Edwards et al., 1997; Storrar and Pratt, 2000), a period in which regulatory accounting requirements were low. In such a context, voluntary disclosure of accounting information has been considered a basic control device that tends to reduce costs linked to the separation between

Marta Macías is a lecturer in the Department of Business Administration and Economics at the Saint Louis University, Madrid Campus, Avenida del Valle, 34, 28003 Madrid, Spain (tel: +34 915545858 x 236; fax: +34 9155334 52; e-mail: maciasm@spmail.slu.edu). 
ownership and control (Berle and Means, 1932; Watts, 1977; Fama and Jensen, 1983). However, direct causal relationship between ownership and external corporate reporting has been contested. For instance, Edwards (1992) compared the reporting practices in nineteenth-century Britain of three different types of institutions, non-regulated firms, regulated firms and municipal corporations, finding similarities that suggest the existence of other additional factors driving disclosure of accounting information. Toms (1998) points out the influence of the social character of share ownership, highlighting the influence of institutional factors on financial reporting practices. This paper aims to contribute to this research stream by analysing the privatization of the Spanish tobacco monopoly. The rise of liberalism since the early years of the nineteenth century induced a deep and enduring debate about the existence of state-owned monopolies. Public intervention was strongly reduced, either through privatizing some industries or simply closing them. The Spanish tobacco monopoly was affected by this trend. After several failed attempts, in 1887 the management of the industry was privatized. The privatization entailed the foundation of a privately-owned company.

The case of the privatization of the tobacco monopoly may be of interest for several reasons. First, because the privatization took place without any modification in the competitive environment. The monopoly was maintained, allowing us to isolate the impact of the change in ownership. Second, historical studies include the temporal dimension in the analysis, allowing us to explore the incentives for the provision of accounting information (Bryer, 1993; Toms, 1998). Third, as was mentioned above, the nineteenth century is characterized by the existence of low regulatory accounting requirements. As Toms (1998) has argued, the search for determinants of accounting disclosure may benefit from the lack of a tight regulatory framework. Fourth, research on financial reporting development has extensively focused on the analysis of Anglo-Saxon contexts. Evidence of other contexts characterized by less developed stock markets, lower competitive pressures, and stronger state intervention, such as the Spanish one, may contribute to enhance our understanding of this issue. Finally, the paper may contribute to broaden our knowledge of nineteenth-century Spanish accounting practices, about which all too little is known (Hernández Esteve, 1995).

This is the second paper which exploits the historical archives of the Tobacco Company of Spain in the nineteenth century. Carmona and Macías (2001) studied the implementation of cost accounting practices in the Royal Tobacco Factory of Seville during the period 1820-87. This paper is differentiated from the former since it focuses on the development of financial reporting practices in the company which emerged out of the privatization of the tobacco monopoly in 1887. Evidence has been gathered from two archives: the Historical Archive of the Tobacco Company in Seville (AHFTS), which contains copies of the annual reports, statistics and additional documentation of the privatized company; and the Historical Archive of the Bank of Spain in Madrid (AHBE), where the documentation relating to the privatization process is deposited. 


\section{Historical background}

The period under study may be characterized by stability, following a period of extreme turbulence. Between 1868 and 1874, Spain tested almost every known form of government, ${ }^{1}$ before the Bourbon monarchy was restored in the latter year. The need to build up a broad base of support for the restored monarchy lead to the construction of a bipolar political game, with conservatives (lead by Canovas) and liberals (under Sagasta's leadership) sharing political power in a peaceful way (Fusi and Palafox, 1997). This situation was possible because of the integration of the more radical elements, of both the right and the left, inside these two major political parties, the system being characterized by a strong pragmatism that exceeded ideological or dogmatic principles. Potential threats to the system were avoided by establishing an organized political rotation. Arrangements incorporating corruption, political manipulation, and fraud were established by which a peaceful turnover of political parties in office was assured, thereby protecting and consolidating the political system (Comellas, 1996). From an economic perspective this period appears characterized by a steady, though slow, rate of economic growth. Public finances experienced a significant improvement, the level of public debt decreasing from 16,070 million pesetas in 1875 to 7,659 million in 1882 (Comin, 1997). Moreover, the public debt as a ratio of Gross National Product fell from 1.38 to 0.70 , reflecting one of the most favourable economic conditions of the century (Tortella, 1995). At the end of the century, the economic and political climate deteriorated, this trend being intensified by the Cuban war (1895) and the final loss of overseas territories after the war against the USA in 1898 .

\section{The Spanish tobacco monopoly under public management}

At the time of privatization, the tobacco industry was a complex one. It consisted of nine factories, 48 provincial warehouses, 549 'dependent administrations', and more than 18,000 tobacconists. Public management was characterized by two basic features. First, multiple agents took care of the different aspects of the industry. The monopoly comprised three different and separated activities: the import of raw material and finished products from overseas colonies; manufacturing; and distribution and sale. The responsibility for the import of raw material was shared among the 'Dirección General de Rentas Estancadas' (Steering Agency for State Monopolies, SASM) and the 'Dirección General de Contabilidad' (Steering Agency for Accounting, SAA). Manufacturing activities fell under the responsibility of the SASM, although the flow of funds were managed by the provincial structure of the 'Dirección General del Tesoro Público' (Steering Agency for Public Treasure). Distribution and sale of finished products were as well under the responsibility of the Steering Agency for Public Treasure. Distribution was organized in three steps. Provincial warehouses received tobacco products from the factories according to the expected consumption in the province they served. From there, products were sent to 
'dependent administrations' that covered a smaller territory and, finally, to the tobacconists as invoices were received. Finally, one of the critical aspects of the industry, the fight against smuggling, was the responsibility of the Army.

This organization introduced additional complexity to the management of the industry, which appears to have been characterized by the tension between centralization in decision making and the degree of non-compliance with the rules. Liberals tried to increase rationality in the public administration, in order to avoid corruption and fraud. As far as the tobacco industry was concerned, seeking for higher rationality meant the implementation of several bureaucratic procedures and the attempt to centralize decision-making.

Although decision making was highly centralized, the lack of compliance lead to a divorce between decision making and action, reinforced by the political instability and the subsequent high turnover of the head officers of the Ministry, that characterized this historical period. For instance, Carmona and Macías (2001) provide evidence as to the variety of responses exhibited by the Tobacco Factory of Seville to institutional pressures implementing budgets and cost calculations. This represented a major obstacle to providing an adequate global vision of the industry from a managerial viewpoint. Finally, and as a consequence, direct public management revealed itself as unable to design and implement a consistent plan of reforms in order to improve the industry's performance.

The industry, though profitable, faced deep efficiency problems, being the major problem assuring an adequate supply of tobacco products (GálvezMuñoz, 1997). Throughout the nineteenth century the industry confronted a situation of excess demand (Comín and Martín Aceña, 1999) that was increasingly aggravated by the bureaucratic procedures and the sluggishness in responding to customer's changing patterns of demand. As a consequence, production was severely unbalanced, and while some highly demanded products were not adequately supplied, others were manufactured simply to be stored (Delgado, 1896). Additionally, administrative rules tied the management of the industry so as to impede any rationalization of manufacturing operations, and raising expenses in critical areas such as transport and purchases.

Second, control mechanisms were characterized by their bureaucratic nature. Although the different agencies were subject to several administrative controls, these mechanisms lacked a managerial perspective, focusing on either political or legal aspects. That is, emphasis was laid mainly upon budget and expenses control, trying to ensure a 'proper' (legal) use of both financial and material resources. Management of the so-called 'Tobacco Income' was the responsibility of the government, who had to render accounts to Parliament, this control being of a political nature. To effect such control, the government required information from the offices, information that had to be examined and audited both by the SAA and the 'Tribunal Superior de Cuentas' (Higher Accounting Court). It is important to note that, following the organizational structure, accounting information did not offer a general picture of the industry, but presented fragmented information on the different areas. Moreover, these agencies oversaw the conformity to the legal rules, but not the efficiency of the 
industry management. As a consequence, the profitability of the industry was not consistently and accurately calculated.

\section{The privatization of the tobacco monopoly}

Motivations for privatizing the industry appear to have been grounded in both ideological and practical factors. As was mentioned above, liberalism brought about a significant reduction in state intervention. Privatization of state-owned companies, which extended to include the tobacco industry, was one of the most important manifestations of this trend. However, the importance of the industry as source of income for the state; ${ }^{2}$ the poor condition of public finances; and the political instability that characterized the nineteenth century led to an ever changing treatment of the industry (Tejerizo, 1975). Debates involved both issues of deregulation vs monopoly and private vs public management. In 1813, $1821,1855,1866$, and 1869 the industry was liberalized but shortly after each change, the monopoly was reinstated, either for political or financial reasons. In 1844 the tobacco industry was leased to a private company but, once again, a political change resulted in the restoration of direct public management. However, in the last quarter of the century, the situation changed and the country entered a period of calmness, both at the political and economic level. In such a context the tobacco industry was definitively leased in 1887 to a private company, the monopoly however being retained.

By 1887 , investment was clearly needed in order either to modernize the industry, such as through the mechanization of some of the productive processes, or to expand the productive capacity through adding new factories to the already existing ones while retaining the existing hand-craft production methods (Alonso Álvarez, 1996). Privatization was supported by the idea that private management would engage in the needed reforms. According to the Treasury Minister who decided upon the privatization, López Puigcerver, the maintenance of public management confronted three major problems: (i) the level of investment required to expand supply; (ii) the speed of the reforms which, under public management, would be slower due to the bureaucratic procedures involved; and (iii) the turnover of head officers in the Ministry, which presented serious difficulties to the design and implementation of a plan of reforms. Therefore, in the opinion of López Puigcerver, the best option was to lease the industry, without deregulating it (Torres Villanueva, 1998).

The Spanish privatization process was inspired by the Italian experience of 1867 (Delgado, 1896). In Italy, the high profits earned by the privatized tobacco company provoked, at the end of the contract, the reinstatement of direct public management. The Spanish Treasury Minister, in order to avoid such a problem, established strict conditions over the company's activities.

The articulation of the privatization represents a crucial feature in understanding the evolution of corporate reporting. Whereas the privatization process was organized as a public auction, the government tried to ensure that a 
particular candidate, the Bank of Spain, would win the bid and, directly or indirectly, take care of the industry. At that time, the Bank of Spain was a large joint stock company, listed on the Madrid stock market. Several reasons might explain the government behaviour. First, it wanted to guarantee the success of the privatization and the protection of the tobacco monopoly. Second, the Bank of Spain, though being a private company, was strongly dependent upon the government. They were linked via several financial businesses and these other activities would act as collateral. Finally, it was a solidly-based organization that could supply the required financial resources.

The Bank of Spain, at first, was reluctant to engage in an industry that could 'denature its exclusive financial mission' (Comisión para el arrendamiento, Legajo 954, AHBE). The government tried to reverse this attitude by providing information about the state and profitability of the monopoly and, more importantly, linking the co-operation of the Bank in this matter with their financial businesses. That is, if the Bank wanted to continue to be the treasurer of the state, to continue to run the operations of the public debt and gold, and to continue to act as a collector of taxes, then it had to take care of the tobacco industry as well (Legajo 954, Operaciones, AHBE). The Bank decided to help the government by bidding for the monopoly. In order to reduce the risk to itself, the Bank decided to create a new company, in which other important financial groups would participate, to manage the industry. However, the Bank arranged to retain a sufficiently large share of the new company's capital to provide it with control over the monopoly. The capital of the Compañía Arrendataria de Tabacos (CAT) was fixed at 60 million pesetas, the Bank retaining half of the shares, the other half being distributed amongst the other financial groups.

The law authorizing the leasing of the monopoly was enacted on the 22 April 1887 (Legajo e-22301, AHBE). The law required that the lessee should be a Spanish company, independent of foreign groups. The term of the contract was fixed at 12 years, and the lease was secured by a deposit by the company of a security 20 million pesetas, in order to protect the state's interests from opportunism and to ensure the company's compliance with all of the contractual conditions. The lease was organzed as an operating franchise, thereby avoiding the need for the new company to acquire the long-term assets. Nevertheless, the level of financial resources needed to bid for the monopoly was substantial. $^{3}$

The contractor was required to pay a yearly rental which was composed of a fixed amount (canon) plus a variable amount that depended on the profits of the year (participation in profits). For calculation purposes, the term of the contract was split into four sub-periods. The canon was fixed at 90 million pesetas for the first three years. In the second sub-period, the fixed amount would be the mean of the net income corresponding to the second and third years of the contract. In the third and fourth sub-periods, the fixed amount would be the mean of the prior sub-period. The net income would be calculated as follows: 
+ Operating revenues (Sales revenue + Commissions on sale of foreign and colonial products)

- Cost of goods sold

- General administrative expenses

- Manufacturing expenses corresponding to the sold products

- 5 per cent interest on invested capital (excluding the fee).

The variable part of the rental depended on the difference between the net income and the canon. If the former was lower than the fixed amount established for that period, the CAT would have to bear the loss. In the opposite case, the surplus would be shared on an equal basis between the state and the company. The relevance of accounting was enhanced by the fact that it represented the basis for the calculation of the rental. This account had to be submitted to the Treasury in order to be supervised and approved. The Treasury wanted to make sure that the expenses were proportional to the level of production.

The calculation of the rental represented a major concern for the CAT. The problem was not linked to its amount (though the 90 million pesetas established for the first three years greatly exceeded the outcomes ever obtained by the tobacco monopoly) but to the calculation of the fixed canon. It became evident that under the method set down, the company had no incentive to increase the profitability of the industry, since any increase in one period would be translated into a higher fixed amount in the following period, the Treasury being the only beneficiary (Delgado, 1896). Thus, in the annual report of 1888-9 Amós Salvador, president of the CAT complained about this issue:

Because of the clauses of the lease contract, that is, in view of the dispositions of the law of the 22 April 1887, the losses experienced by the Company are to be borne by itself, while the monopoly profits are not only to be shared with the State, but produce an increase in the canon for the following period. As a consequence it follows that the Company has no essential interest in developing these profits; because if the Income experiences a progressive improvement, the profits it will receive in a period is less than the profit that it will receive in the next, by virtue of the increase in the canon; but it happens that if Income falls, in this case, because of the profits achieved in the former period and due to the increase in the canon, a loss, maybe irreparable, for the Company will be derived.

(Memoría 1888/89, CAT. AHFTS)

On the other hand, at the business level, decision making in relation to crucial aspects such as investment, product mix, pricing and human resources were the subject of intervention by the public administration. For instance, article 11 imposed on the CAT the maintenance of the existing products, any modification in their composition, number or price requiring the approval of the government. Likewise, new investment in factories and warehouses were fixed by the contract (article 8), as was the case of manufacturing employees, where the contractor was required to keep 75 per cent of the workers in every factory (article 8 ). The contract also included public monitoring mechanisms. A governmental delegate, 
who could impose a veto on any decision potentially likely to damage the public interest, was placed at the company's headquarters (article 22).

As the conditions imposed by the contract were severe, private management of the tobacco industry did not result in a dramatic increase in the volume of production, nor in profitability or in the level of investment. The financial pressure, the limited competencies of the CAT in respect of investment or production strategies, and the required maintenance of employment impeded the introduction of mechanization. As a consequence, the Company focused its cost-cutting activities on the reorganization of the work in the factories. Three main objectives were pursued: (i) the achievement of a common organization that could clearly set duties, responsibilities and accountability at all levels of the hierarchy; (ii) increasing uniformity within production processes and products; and (iii) the augmentation of the quality of production:

Surely, everyone can easily realise the important difficulties the Company is facing in order to achieve the desired organisation of the Factories, which can be said to be as diverse in its development as the number of existing factories. Prescribing the former organisation, developing a new one that allows us to allocate to all and every employee their pertinent duties, will make possible the assignment of responsibility for the faults they may cause, and will assure order and regularity in those facilities [. . . . In this way the Company is trying to achieve improvements in the quality of production, economies in manufacturing activities and the required organisation in the factories.

(Annual Report 1888/89: 11)

A critical factor in achieving these objectives was to enhance discipline within the factories. The CAT tried to reduce the level of absenteeism and to establish rigid timetables. However, in this aspect it had to fight against a strongly internalized work culture. ${ }^{4}$ Only the massive introduction of machines in the twentieth century made it possible to impose a tighter disciplinary regime on cigar rollers (Valdés, 1989; Baena, 1993; and Gálvez Muñoz, 1997). Mechanization required a completely different organization of the workshops, and entailed a different relationship between worker and products as control over the whole production process was no longer held by individual workers.

The CAT could improve the profitability of the industry by rationalizing distribution. Outbound logistics were redesigned, in an attempt to eliminate the sequence of factories-provincial warehouses-dependent administrations in those cases where sea or railway transport represented effective alternatives. In this way, cost savings were achieved, both by profiting from cheaper modes of transport and by reducing damage and waste in merchandise. For instance, the statistics included in the 1891 Annual Report showed a decline in the ratio of transport expenses to total expenses from 1.484 per cent in 1887 , to 1.078 per cent in 1891. Cost savings were also achieved in the acquisition of secondary materials (paper, boxes, etc.). For example, new contracts with paper suppliers allowed a saving 2 million pesetas in $1887 / 88$; in that same year there was also 
an average decrease in the cost of each bottle of 1.5 pesetas (Delgado, 1896). In spite of these efforts, during the first three years, CAT incurred losses (see Table 1). From 1890/91, however, CAT recorded profits and distributed dividends accordingly from 1892 .

\section{Privatization and accountability}

The association between accountability and ownership is well established in the literature. The relationship between shareholders and managers is an agency relationship that brings about the need for monitoring manager's activities. It is assumed that expenses in monitoring will tend to reduce agency costs, publication of accounting reports representing one of the major monitoring devices. Disclosure of accounting information has been seen for a long time as an effective means of ensuring that managers would act in the interest of shareholders (Fama and Jensen, 1983).

A major factor explaining the emergence and severity of agency problems is diffuse ownership of larger enterprises (Demsetz, 1995). Owners of a corporation that is very diffusely owned have low incentives, or are unable, to discipline professional management. Changes in ownership structure are, therefore, assumed to influence the incentives for monitoring management's activities. This is especially true of privatization processes. In state-owned firms or activities, the ultimate owners, the citizens, have little incentive to control managers, since they delegate control to the state, and cannot claim for residual cash flows.

The economic literature predicts changes in management behaviour as a consequence of the emergence of new business relationships and constraints (Stiglitz, 1988; Parker, 1993): (i) managers may be answerable to shareholders; (ii) the threat of shareholders will depend upon the cost of monitoring managerial effort and upon the concentration of their power. Managers, under the pressure of internal and external controls, will tend to follow those strategies that result in shareholder satisfaction. In addition to the responsibility towards shareholders, managerial activities will be controlled externally (Jensen, 1989; Zeckhauser and Horn, 1989). Stock markets, through the threat of take-over (Wright and Thompson, 1994), and the threat of bankruptcy (Vickers and Yarrow, 1988; Stiglitz, 1989), will contribute to the monitoring of managers.

In general, research has addressed cases in which ownership determines both the objective and the monitoring systems of the firm (see Bös, 1991). The basic assumption is that, in public firms, the state monitors the managers in order to maximize social benefits, while in private firms the management of the firm is controlled through the capital market (or financial organizations) in order to ensure profit maximization. Monitoring systems in public firms are expected to be bureaucratic, accountability being characterized by its focus on conformity to legal rules. On the contrary, under private management the main concern is to ensure the efficient use of financial resources. 


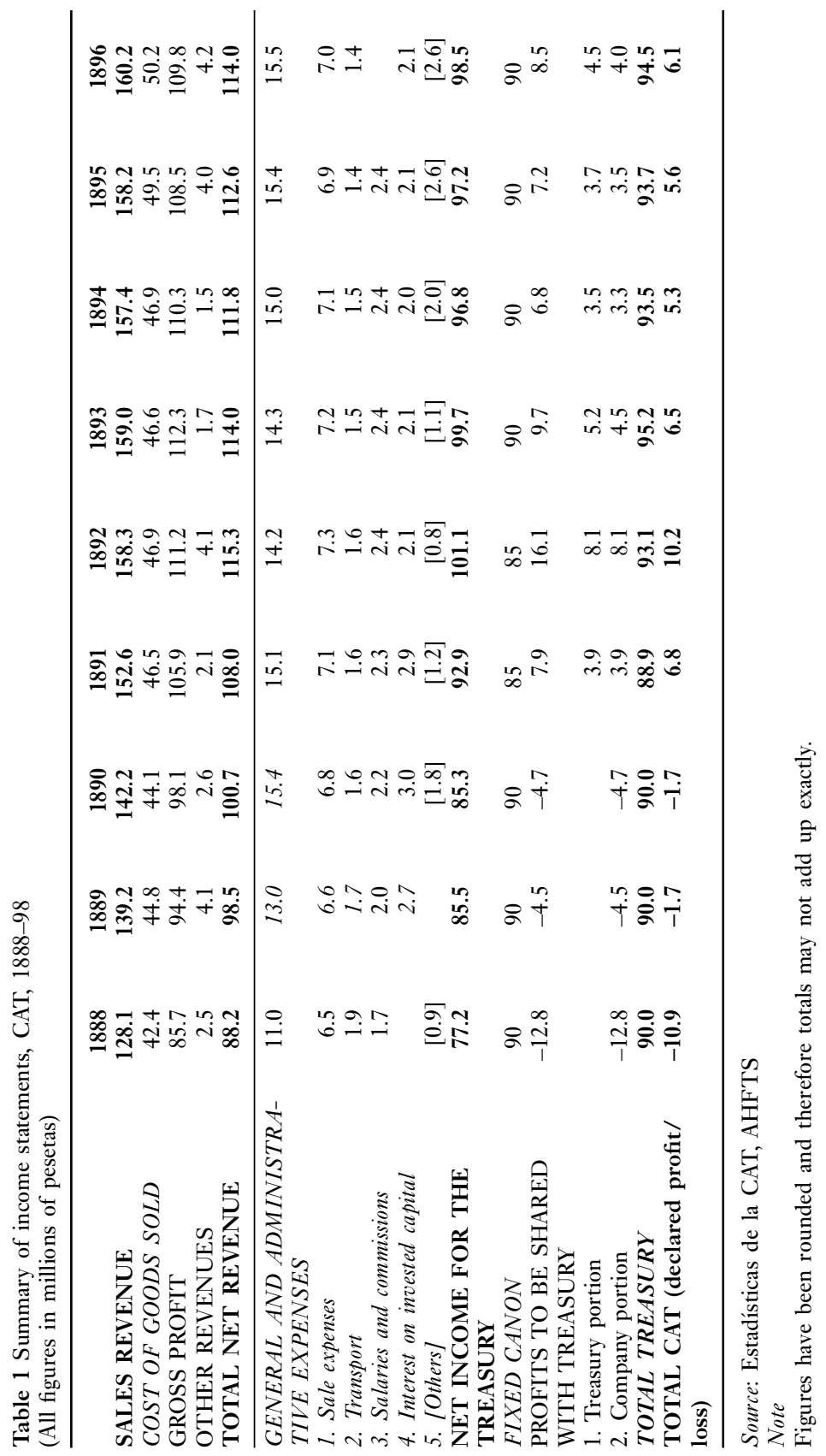




\section{Annual reports of the CAT}

The privatization of the Spanish tobacco monopoly meant a change in the object of control, emphasizing economic aspects, instead of the legal ones that constituted the central concern under public administration. The privatization implied the creation of a joint stock company. The 1885 Code of Commerce which regulated limited liability companies included requirements for the publication of monthly and yearly balance sheets, but gave no insights as to particular requirements or criteria by which to present accounting information. A monthly balance sheet was drawn up by CAT, both as a result of legal requirements (article 157 of the Code of Commerce) and for the purpose of determining interim dividend payments (article 35 of the Company's Statutes). However, while the emergence of financial reporting appears to have been primarily linked to the change in the legal framework, the content of the annual reports largely exceeded both legal requirements and the disclosure practices of private industry generally.

The board of directors was required, according to the statutes of the Company, to present to their shareholders at the company's annual general meeting a balance sheet. This statement should include 'all the Company's accounts related to the period, that have to be submitted to the shareholders for approval adding the proper justifications and the memory of the operations' (leg. no. 1, e 23510, AHBE). 'Justifications' were provided mainly through a large number of financial statements, as will be shown below. The 'memory' of the operations lead annual reports to comprise highly detailed narrative descriptions of the main activities developed by the firm, focusing especially on the problems the company was facing. It also included a section detailing the evolution of the firm's activities throughout the period that had elapsed between the drawing up of the yearly accounts (30 June) and the annual general shareholders meeting, which was held in February.

The early reports were variable in nature, there being differences both in the number and the structure of the financial statements. However, the statements may be grouped into three main categories: (i) balance sheet and income statements; (ii) statements providing greater detail in relation to the income statement; and (iii) statements providing information on the operations carried out during the year.

Balance sheet and income statements were supposed to provide a summarized and general outline of the company's situation, while the other statements provided further information both on the items in the income statement and on managerial aspects. The structure of the balance sheet (see Figure 1) reflects the peculiarities of the leasing contract, the most important features being as follows:

The balance sheet included three different categories of long-term assets. As the privatization was organized as an operating franchise, ownership of the assets as at 22 June 1887 was retained by the state. The company was transferred the right to use and exploit those assets, with a duty of returning them in good condition to the state at the end of the contract. Therefore, these assets were 
recorded both as assets and liabilities. The last category comprised the investment undertaken by the company, whether significant improvements to state-owned assets, or the purchase of new ones. These investments were to be acquired by the state at the end of the contract.

In a similar vein, depreciation, while considered, was not included in the balance sheet. Since depreciation only affected the calculation of the yearly profit, it was therefore only included in the income statement. Moreover, depreciation expenses were not recognized by the state in the calculation of the rental, affecting only the company's net income. The reason why is to be found

\begin{tabular}{|c|c|}
\hline ASSETS & PESETAS \\
\hline Bank of Spain, current account & $1,166.916 .21$ \\
\hline Monopoly leasing contract. fec & $19,121,071.48:$ \\
\hline Factories, tobacco leaves in stores & $8,803,807.90$ \\
\hline Factories, packaging, bottling and manufacturing tools & $402,260.03$ \\
\hline Factorics, products in workshops & $572,183.38$ \\
\hline factories, stored products & $12,984,838.81$ \\
\hline Factories general manufacturing expenses & $1,314,155.25$ \\
\hline Factories profits/losses in raw materials & $285,698.47$ \\
\hline Factories, cash & $2,170,079.00$ \\
\hline Materjals on the way & $4,017,422.01$ \\
\hline Representatives - depositors, tobacco account & $29,039,756.53$ \\
\hline Buildings, machinery and equipment owned by the state & $11,715,272.76$ \\
\hline Buildings, machinery and equipment owned by the Company & $194,449.93$ \\
\hline Public treasure, prepaid rental & $90,000,000.00$ \\
\hline Notes for bronze coins revenues in treasuries & $59,536.35$ \\
\hline Furniture and equipment owned by the company & $66,508.40$ \\
\hline Organization costs & $379,358.91$ \\
\hline Administrative expenses & $9.630,172.75$ \\
\hline Deposited fees & $8,417,000.00$ \\
\hline Public Treasury, to baccos and bottling received & $2,575,298.43$ \\
\hline Confiscation & $\begin{array}{r}260.787 .09 \\
203,176,573.69\end{array}$ \\
\hline \multicolumn{2}{|l|}{ LIABLLITIES } \\
\hline Capital & $60,000,000.00$ \\
\hline Current accounts & $4,078,323.07$ \\
\hline Public Treasury, buildings, machinery and equuipment & $11,716,679.89$ \\
\hline Difference betwcen provisional cost and salc price of stored products & $106,839,923.09$ \\
\hline Profits and losses & $2,399,816.99$ \\
\hline Sale of used bottling & $126,309.13$ \\
\hline Canary Tobacco, to be sold at commission & $333,522.42$ \\
\hline Representatives - depositors, cash account & $8,588,174.56$ \\
\hline Fecs depositors & $8,417,000.00$ \\
\hline Notes payable & $424,164.60$ \\
\hline \multirow[t]{2}{*}{ Various } & $252,659.94$ \\
\hline & $203,176,573.69$ \\
\hline
\end{tabular}

Source: Memoría CAT, 1887/88, AHFTS

Figure 1 Balance sheet of CAT as at 30 June 1888 (translation) 
in the articulation of the privatization as a lease. All assets were supposed to revert to public ownership at the termination of the lease and the matter of depreciation would only be considered at that time, to determine the value of assets, both so as to establish whether the company had any additional responsibility re. state-owned assets, and to estimate the purchase price of the assets purchased by the company during the period of the lease. Depreciation was not, however, consistently considered. For instance, in 1887/88 and $1890 / 91$, the income statements failed to show depreciation expenses. By $1892 / 93$, however, the company also included depreciation of 'organization' costs, i.e. capitalized costs linked to prepaid expenses of the central offices.

This inconsistency in the presentation of the balance sheet is especially noticeable in relation to gains. These included, in different ways, unrealized gains on stored products. In some periods these gains were recorded as the 'Difference between provisional cost and sale price of stored products' or as 'Unrealized gains', while in other accounting periods gains were disclosed, including 'Provisional cost of products' with debit balance, and 'Gains on products sale'. Both 'Gains on product sale' and the 'Difference between provisional cost and sale price of stored products' were important items, which represented around 45 per cent of total liabilities and shareholders' equity.

Two income statements (see Figures 2 and 3) were provided in order to show the evolution (Annual Reports of the CAT, 1887-96) of both the profits and losses for the shareholders and the evolution of the tobacco income for the Treasure. The criteria to determine both outcomes were not equivalent, therefore, income statements also provided a 'reconciliation' of both figures. The Treasury only accounted for economic operations; financial incomes and expenses, and gains or losses derived from changes in the market value of financial assets were not included as elements in order to determine the rental. Likewise, some value adjustments relating to raw materials and other manufacturing expenses, and the payment of the rental were not included in the calculation of net income.

The other statements provided highly detailed information on such issues as: production volume per factory and product; product costs; product margins; tobacco leaves consumed in the different production processes, waste and inefficiency; personnel, overheads, bottling and packing expenses; and a general statement of sales, including both manufactured and imported products. As an example, the 1888-9 annual report included the following accounting statements:

1. Balance sheet

2. Income statement for the 'tobacco income'

3. Income Statement for the Company

4. Gains on sale of Spanish products
5. Gains on sale of Cuban products

6. Gains on sale of Philippine products

7. Gains on sale commissions of Philippine and Canary Islands products 
8. Sales revenues of confiscated products

9. Import taxes over tobacco imports

10. Financial profits

11. Expenses in the commercial provincial structure

12. Central administration general expenses, expenses in fighting against smuggling, central distribution and general store of Santander expenses

13. Manufacturing cost by factories

14. Tobacco leaves invested

15. Gains on tobacco leaves in the Company's factories

16. Losses on tobacco leaves in the Company's factories

17. Destroyed packing and bottling

18. Reparation expenses corresponding to wooden packing

19. Remaining packing stored in the administrations

20. Restored packing valued at contractual price
21. Gains on sale of waste

22. Statement showing the distribution of the balance of losses and gains on tobacco leaves, which are apportioned to the manufactured products

23. Statement showing manufacturing costs, which are apportioned to the manufactured products

24. Statement showing stored tobacco leaves at the end of the period $1887-8$ and those acquired in the period $1888-9$

25. Tobacco leaves stored at the end of June 1889

26. General summary of tobacco and bottling sales

27. Stored Peninsular tobacco and Havana and Philippine cigars, old contracts, as at June 1889

28. Stored modern Cuban products as at June 1889

29. Stored Philippine products, new contracts, as at June 1889

Additionally, the notes to the annual reports offered information on the firm's activities, focusing especially on cost improvements. Statistics (Annual Report, 1890/91, CAT) reflecting the evolution of manufacturing costs, gross margin, transport and distribution costs showed the effort the company was expending in order to enhance performance, emphasizing the growing efficiency in the use of raw materials (see Table 2). The company tried to justify the losses, explaining carefully the difficulties it was facing, given the constraints of the contract, and focusing its comments on those variables, such as transport or distribution, that were under the firm's control.

The main change in corporate reporting is found to occur in $1893 / 94$. At this time the information included in the annual reports experienced a dramatic reduction, both in terms of the narrative account and the financial information disclosed. Only the balance sheet and income statements were included, all the remaining items being discarded. This change was justified by the firm in the following terms: 'those documents are not going to be published this year, because, given their development, the Board of Directors thought it was convenient to omit them from the Memory ...' (Annual Report, 1893/94: 12). 


\begin{tabular}{|c|c|c|c|c|}
\hline PROHITS & $\begin{array}{l}\text { SALES } \\
\text { REVENUE }\end{array}$ & $\begin{array}{l}\text { COST OF GOODS } \\
\text { SOLD }\end{array}$ & PROFIT & $\begin{array}{l}\text { TOTAL } \\
\text { GENERAL }\end{array}$ \\
\hline SALES & Pexetas & Peselas & Pesctas & Pesetas \\
\hline \multicolumn{5}{|l|}{$\begin{array}{l}\text { Peninsular products (Staternent } n^{\circ} 4 \text { ) } \\
\text { Modern class: }\end{array}$} \\
\hline Kilogsams & $48.356,687.51$ & $13,563,148.46$ & $34,793,539.05$ & \\
\hline Thomsands & $85,791,894.77$ & $27,407,132.38$ & $58,384,762.39$ & \\
\hline Otd class: & $33,132.45$ & $6,883.44$ & $26,249.01$ & \\
\hline Thousands & $901,115.77$ & $330,104.12$ & 571.016 .65 & \\
\hline \multicolumn{5}{|l|}{ Havana products (Statcrient $n^{\circ} 5$ ) } \\
\hline Modern & $2,400.671 .53$ & $1,995,079.36$ & $405,592.17$ & \\
\hline Oid & 73.558 .55 & $35,821.66$ & $37,736.89$ & \\
\hline \multicolumn{5}{|l|}{ Whilippine products (Statement $n^{\circ} 6$ ) } \\
\hline Modern & $1,508.399 .51$ & $1,332,100.28$ & 176.299 .23 & \\
\hline & 17.623 .65 & $7,730.18$ & $9,893.47$ & \\
\hline \multicolumn{5}{|l|}{ Proxfucts in commission (Statement $n^{\circ} 7$ ) } \\
\hline Canary & $111,454.80$ & $76,903.79$ & $34,551.01$ & \\
\hline Philippine & $1,582.50$ & 465.20 & $1,117.30$ & \\
\hline \multirow[t]{2}{*}{ Contiscated products (Statement $n^{\circ} 8$ ) } & 7.560 .50 & $7,560.50$ & & \\
\hline & $139,203,681.54$ & $44,762.929 .37$ & $94,440.752 .17$ & \\
\hline \multicolumn{5}{|l|}{ Used bottlings: } \\
\hline \multicolumn{2}{|c|}{$\begin{array}{l}\text { Sales in the current period atrount } \\
\text { To be deducted: Because of their inclusion in the last period }\end{array}$} & $\begin{array}{l}151,170.61 \\
-15,405.90\end{array}$ & $135,764.71$ & $94,576.516 .88$ \\
\hline \multirow{2}{*}{\multicolumn{5}{|c|}{$\begin{array}{l}\text { OHER PRODUCTS } \\
\text { - Inmort taxes on fobaccos imported by citizens (Statentent } \pi^{\circ} 9 \text { ) }\end{array}$}} \\
\hline & & & & \\
\hline \multicolumn{3}{|l|}{ - Idern id. id. by the Corspany } & 744.768 .77 & $3,580,960.72$ \\
\hline \multicolumn{4}{|l|}{ - Outcomes of raw materials contrgcts } & $751,953.15$ \\
\hline \multicolumn{4}{|c|}{ - Rectification tor excess in the valuation of tobaccn leaves in the former period } & $336,059.77$ \\
\hline \multicolumn{4}{|l|}{ INTERLST } & \\
\hline \multicolumn{4}{|l|}{ - Over prepaymeuts to the Truasury } & $1,368.595 .89$ \\
\hline \multicolumn{4}{|c|}{ PLBLIC FLNUS } & \\
\hline \multirow{2}{*}{\multicolumn{4}{|c|}{ - Profit in the depreciation, forcign curency and interests in tilte owned by the State (Statement $n^{0} 10$ ) }} & $1.798,252.50$ \\
\hline & & & & $102.4 ! 2.338 .91$ \\
\hline
\end{tabular}

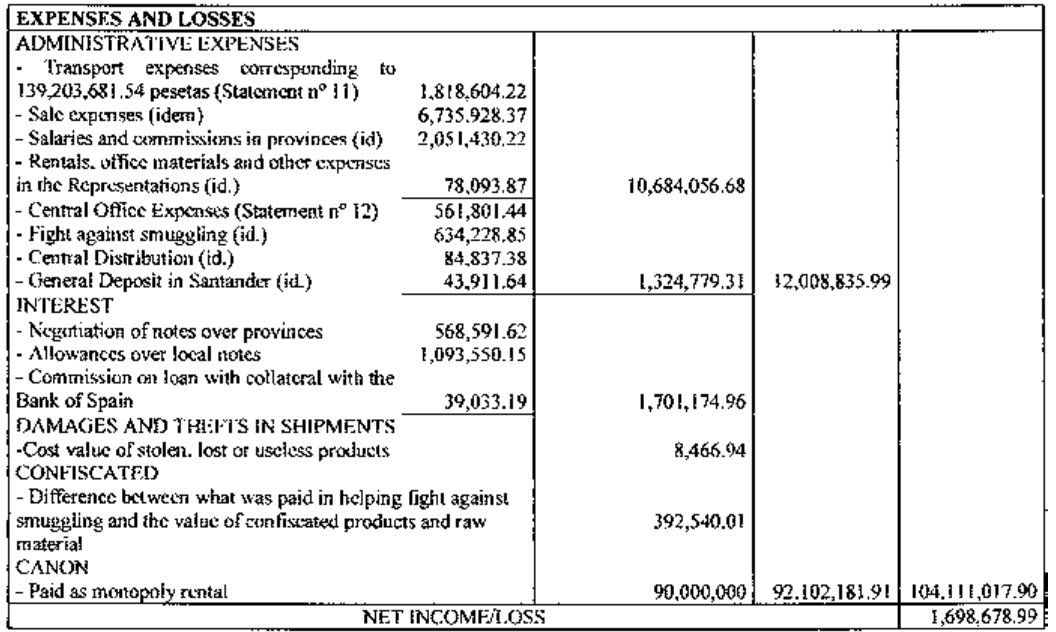

Figure 2 Income statement of CAT, 1888 (translation) 


\begin{tabular}{|c|c|c|c|}
\hline $\begin{array}{r}\text { CONCILIATION BETWEEN INCOME AS REPORTE } \\
\text { COMPANY, EXPRESSING TIEMS THAI SHOULD BE I } \\
\text { TIIE LATTER AND VIC }\end{array}$ & $\begin{array}{l}\text { TO THE GO } \\
\text { CLDHE IN T } \\
\text { VERSA }\end{array}$ & HE FORME & $\begin{array}{l}\text { DTIE } \\
\text { JT NOT IN }\end{array}$ \\
\hline Net incorac that slabli be used as a basis to fix the canmon for the & second period & $83,556,347.15$ & \\
\hline PROFITS & & & \\
\hline - Interest depreciation and exchange expcnses on public debt & $1,798,252.50$ & & \\
\hline - interest on kan to the Treasury & $1,368,595,89$ & & \\
\hline - 5 per cent interest on invested capital & $2,786,696.22$ & & \\
\hline $\begin{array}{l}\text { - Correction because of overvaluation on tobacco leaves } \\
\text { invested in the prior period }\end{array}$ & 336.059 .77 & & \\
\hline $\begin{array}{l}\text { - Onteonte of zaw material contracts in } \\
\text { the two years }\end{array}$ & & & \\
\hline - deduct- outcomes of the second period & $581,612.99$ & 6.871 .217 .37 & \\
\hline & & 90.427 .564 .52 & \\
\hline 1,OSSHS & & & \\
\hline - Monopoly Rental & $90,900,000$ & & \\
\hline - Negotiation of notes over provinces & $568,591.62$ & & \\
\hline - Allowances on local notes & $1,093,550.15$ & & \\
\hline - Commission and interest on the loan with the Bank of Spain & $39,033.19$ & & \\
\hline - Thefts and darmages & $8,466.94$ & & \\
\hline $\begin{array}{l}\text { - Used bolties soild, that correspond to the previous year } \\
\text { - Hxcess on expenses over the value of }\end{array}$ & $15,105.90$ & & \\
\hline confiscated products, lota! 392,540.01 & & & \\
\hline $\begin{array}{l}\text { - Less what corresponds to the current } \\
\text { period }\end{array}$ & $209,026.21$ & & \\
\hline $\begin{array}{l}\text { - Higher cost to the products of the eurrent poriod because of } \\
\text { kusses and expenses not considerco in the former }\end{array}$ & $192,169.50$ & $92,126,243.5\}$ & $1,698.678 .99$ \\
\hline
\end{tabular}

Source: Memoría 1888-9, CAT (AHFTS)

Figure 2 (continued)

\section{Determinants of accounting disclosure}

Accounting literature has addressed the study of voluntary accounting disclosure from a variety of perspectives. Several factors have been found to be significant in explaining the level of disclosure. Incentives to provide information have been found to increase with financial leverage (e.g. Dhaliwal, 1980; Chow, 1982; Bradbury, 1992), when firms quote at stock markets (e.g. Leftwich et al., 1981); the more diffused is ownership (e.g. McKinnon and Dalimunthe, 1993) or the higher is market uncertainty (Sengupta, 1998). Hence, theory development and empirical work has yielded mixed results and the determinants of accounting disclosure are still not well developed.

\section{Omnership structure and corporate reporting}

Ownership structure has been traditionally considered a major determinant of voluntary disclosure of information (Jensen and Meckling, 1976; Fama, 1980). Berle and Means (1932) developed the separation thesis, which contends that corporate ownership is widely diffused among small shareholders unable to impose a certain discipline on managers. In the absence of effective shareholder control, the only effective way to assure that managers are acting in the interest 


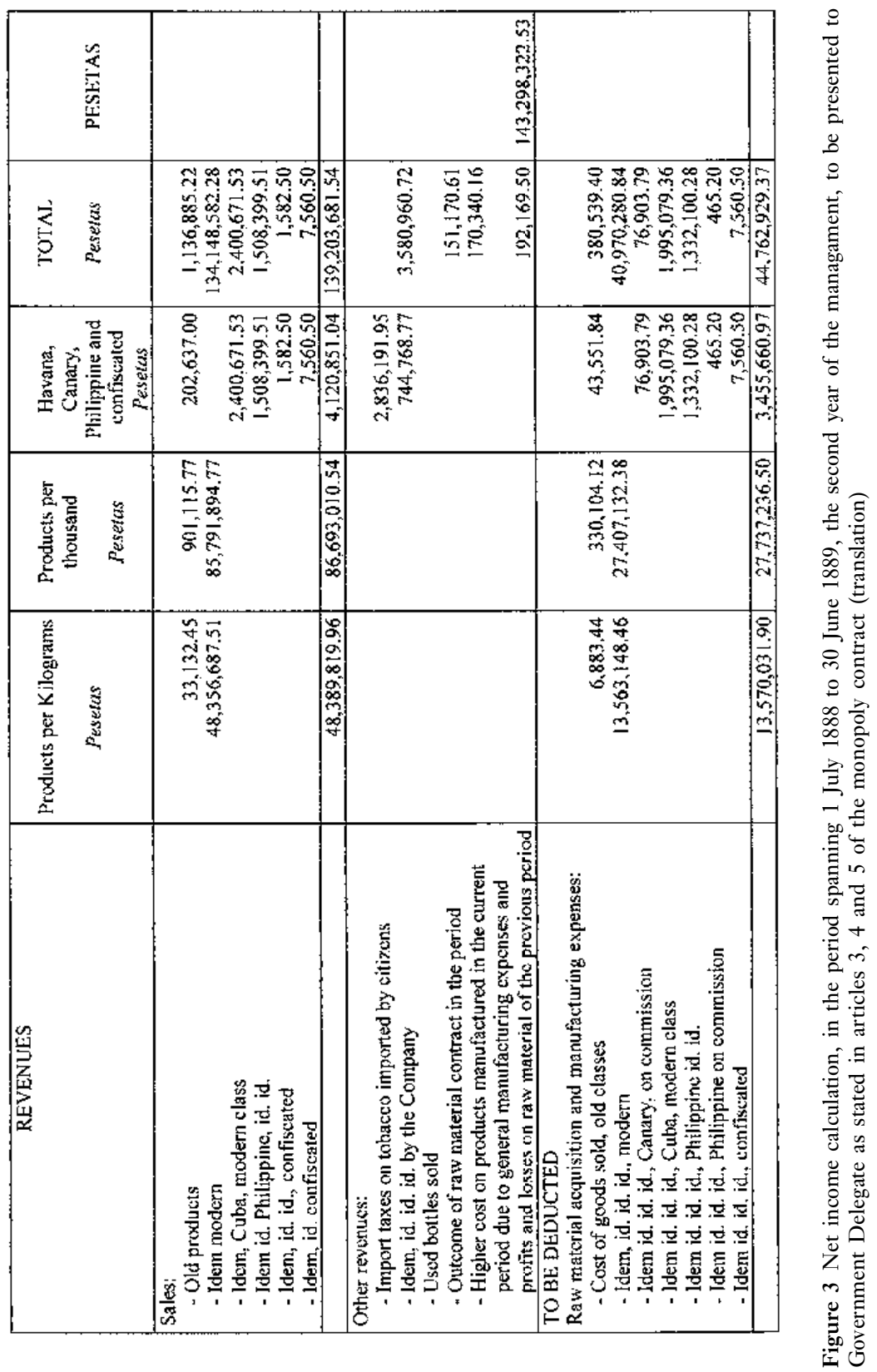




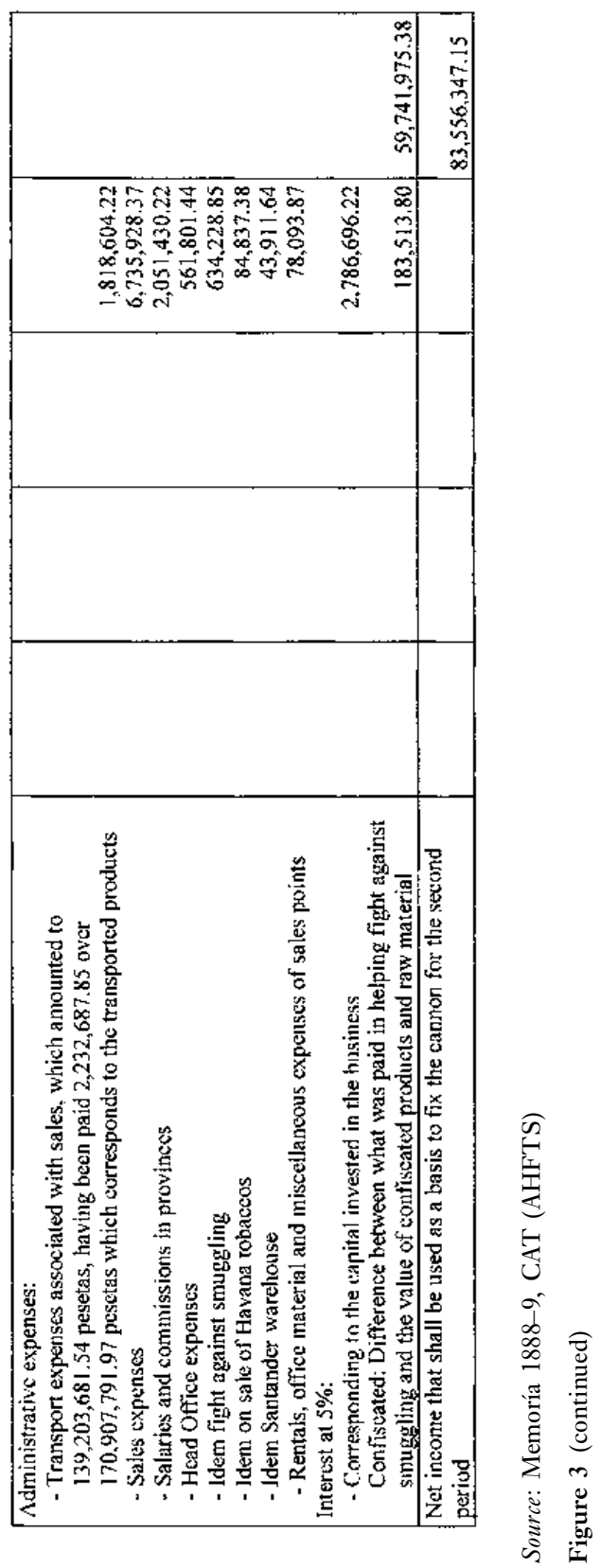


Table 2 Ratio statistics included in the CAT Annual Report 1890/91 (All figures are percentages)

\begin{tabular}{cccccc}
\hline $\begin{array}{c}\text { Manufacturing } \\
\text { cost to sales } \\
\text { value of } \\
\text { production }\end{array}$ & $\begin{array}{c}\text { Income } \\
\text { to cost }\end{array}$ & $\begin{array}{c}\text { Income to cost } \\
\text { of Peninsular } \\
\text { products }\end{array}$ & $\begin{array}{c}\text { Transport cost } \\
\text { to total } \\
\text { manufacturing } \\
\text { cost }\end{array}$ & $\begin{array}{c}\text { Distribution costs } \\
\text { to total } \\
\text { manufacturing } \\
\text { cost }\end{array}$ \\
\hline $1887 / 88$ & 32.417 & 208.477 & 206.076 & 1.484 & 5.075 \\
$1888 / 89$ & 29.833 & 235.196 & 227.119 & 1.306 & 4.839 \\
$1889 / 90$ & 29.376 & 240.403 & 241.207 & 1.146 & 4.813 \\
$1890 / 91$ & 27.782 & 259.937 & 247.106 & 1.078 & 4.688 \\
\hline
\end{tabular}

Source: Memoría 1890/91 de la CAT, AHFTS.

of shareholders is full disclosure of information. However, while ownership structure is clearly highly diffused among large corporations, ownership appears to be sufficiently concentrated to provide strong incentives to large shareholders to influence management (Jensen and Meckling, 1976; Shleifer and Vishny, 1986; Demsetz, 1995). As a consequence, monitoring and control costs will be lowered when the rights of control are concentrated in large shareholders with presence on the board of directors (Jarrel and Poulsen, 1987; Agrawal and Mandelker, 1990; Prevezer and Ricketts, 1994) reducing incentives to disclose information.

The evidence put forward in this paper is not consistent with this argument. By 1888 , the five major shareholders controlled 33.36 per cent of the capital with only a further 50 shareholders possessing more than 200 shares (representing 13.23 per cent of total capital). When the first shareholder's annual meeting took place, there where two main shareholders: the Bank of Spain (which owned 20.5 per cent of the shares) and the Urquijo Bank (7.63 per cent). The remaining capital was distributed among a widely dispersed set of shareholders. Under the Company's Statutes, only shareholders owning more than 20 shares had a right to attend, and to vote at, the annual meeting. With a total of 885 such shareholders, and the Company's Statutes requiring a two-thirds majority on any vote, the Bank of Spain was able to exercise a significant degree of control over the company's activities.

The dominant position of the Bank of Spain was strengthened because of three additional factors. First, the Bank became the sole financial institution serving CAT and, thus, intervened in all its activities (article 37 of the Company's Statutes, AHBE). Second, the Bank had a majority of the members of the board of directors:

Once the issue of the social capital was solved, the Commission thought that it should reserve for the Organisation the majority in the Board of the new Society, as a fundamental guarantee of the franchising management, both to the Bank itself and to HM. government in their reciprocal relationships.

(AHBE, Operaciones, no. 954. Arrendamiento de la renta del tabaco. Estado actual de la cuestión) 
Eleven members comprised the board of directors: the general manager and vice-director of CAT, five members of the Bank of Spain's board and four representatives of the remaining shareholders. Additionally, the general manager of the company was the president of the board. Management was completely centralized in the board of directors whether at the strategic or the business level. Third, the Bank was locked in to this investment. Whereas other shareholders could easily sell their shares on the stock market, the Bank was linked to the tobacco business by the commitment it had entered into with the government. Therefore, it had a strong incentive to exert direct control.

The particular circumstances that forced the Bank of Spain to bid for and manage the tobacco monopoly provided a great incentive for it to participate in the management of the business. While strong incentives for direct monitoring are assumed to be associated with low disclosure of accounting information, annual reports from 1887 through 1893 included large amounts of financial and managerial information. Financial reporting could have been influenced by the Bank of Spain's own disclosure practices which exceeded both legal requirements and industry practice (Annisette and Macías, 2002). However, in spite of the lack of change in the leading role played by the Bank, the CAT's disclosure policy had changed dramatically by $1893 / 94$. Hence, whilst the emergence of corporate reporting appears to be linked to ownership transfer, other additional factors are required to explain changes in the information disclosed. Furthermore, whereas theory has focused on assuming the emergence of a new managerial class as a major determinant of financial accountability, this case provides additional evidence of situations in which capital interests prevailed (Bryer, 1993; Toms, 1998).

\section{Stock markets, financial institutions, and corporate reporting}

Accounting disclosure can be explained in terms of funding needs. It is assumed that firms will tend to increase the level of information provided to stock markets and financial institutions, trying to either ease the capture of resources or limit the consequences of bad performance (Dhaliwal, 1980; Chow, 1982; Bradbury, 1992).

The new company went public shortly after its foundation, being listed on the Madrid Stock Market. During the first three years the company's share price showed a decline as a consequence of the firm's losses, the index of share price to par value (100) falling from 113.9 in 1887 to 87.8 in 1891 (Comín and Martín Aceña, 1999). From then on, the trend was reversed, and the share price experienced a continuous rise (1893: 155.3; 1899: 295.7; and 1900: 409.1). This rise was in marked contrasted to share prices generally, the stock market experiencing a strong crisis from 1895 to the end of the century, provoked by factors such as the international crisis and the subsequent massive withdrawal of foreign capital from the Spanish market, the assassination of Prime Minister Cánovas, which increased political uncertainty, and the loss of the colonies (ICAGBM, 1981). 
The influence of the stock market on CAT appears to have been limited for two main reasons. First, it is important to remark that the Spanish Stock Exchange was not very active as it was mainly devoted to trading public debt securities. The number of listed private companies was low (28 in 1874; 48 in 1882 and reaching only 60 by 1900). Railways, mining and financial institutions with a large proportion of foreign capital represented the bulk of private shares (SRBVM, 1993). Additionally, the influence of a stock market is based on the relevance of public information for shareholders. However, large Spanish investors constituted a small and powerful elite that participated in all the important financial operations and had access to private sources of information (e.g. Ringrose, 1996; Cruz, 1996, 2000; de la Fuente, 2000). ${ }^{5}$ Second, the company itself had a limited dependence on the capital market as a provider of funds. On the one hand, the capital structure remained stable throughout the period of study: no additional capital was issued. On the other hand, as the Bank of Spain was the sole financial institution with which the company could deal, accounting disclosure cannot be assumed to have derived from the need to reassure fund providers.

\section{Market uncertainty}

Sengupta (1998) contends that market uncertainty has a positive impact on accounting disclosure. He argues that suspicion regarding the capacity of firms to survive (that is, when the market uncertainty is high), increases incentives to disclose information. In the case of the privatization of the tobacco monopoly, the company had to face uncertainty emerging from different sources.

The privatization of the tobacco monopoly was justified by the government in terms of the superior efficiency that private management would achieve, and the resultant increase that would accrue in the state's revenues. The privatization gave rise to deep political and social debates. The discussions preceding the privatization drove the government to be, probably, extremely cautious.

It is impossible to forget the atmosphere created against the Minister who undertook, both as a patriot and with resolution, the task of leaving to the private management such an important income as the Tobacco one, it may happen that its influence drove him to exaggerate the contractual conditions, without seeing clearly its mistakes.

(Santías and de Figueroa, 1900: XVII)

The government selected the contractor very carefully. Nevertheless, one of the main features of the privatization process was the mistrust which the government exhibited towards the CAT, which was reflected both in the clauses of the leasing contract and in the active intervention of the governmental delegate. The tensions between the company and the state are well documented in Comín and Martín Aceña (1999), who point out a number of areas of conflict which sometimes had to be resolved in court. ${ }^{6}$

The leasing contract favoured the rise of uncertainty for two main reasons: the term of the contract and the calculation of the rental. On the one hand, 
twelve years were considered by the Company as insufficient to obtain an adequate return if important investments were to be made, and the government never gave any insights regarding a potential continuation of the lease. On the other hand, the problems derived from the calculation of the rental have been already described. Soon after the privatization, the company began to press for a change in these conditions. In order to obtain more favourable contractual conditions, it was important to build up a positive and solid reputation, and annual reporting contributed to this issue.

By 1892, the company achieved one of these objectives. The Budgetary Law of 30 June, article16 (AHBE, legajo 1, e22310) changed the calculation of the results towards a system in which the fixed amount was to be 90 million pesetas and establishing a variable share of the participation in profits. That is, if the net income comprised between 90 and 96 million pesetas the participation of the state in the surplus would be 50 per cent; from 96 to 100 the percentage would be 60 per cent; and from 100 million up it would rise to 65 per cent. This reform benefited both the company and the state. The fixed canon increased, thus assuring a higher minimum for the state, while, at the same time, assuring that increases obtained in one period would not damage the interests of the company in the following one. This was an important point, because the tobacco consumption also depended on factors not controlled by the firm as, for instance, the organization of the fight against smuggling, the economic cycle or the existence of diseases or wars.

Another important factor arises from the organizational changes derived from the reform of 24 April 1894. Throughout the period analysed in this paper, the CAT was characterized by a strong concentration of power in the person of the president and general manager which immediately created problems for the company. The turnover of presidents was very high, as political motives influenced the replacement of incumbents. Thus, from 1887 to 1896 , nine different presidents held office (see Table 3). To ensure a smooth relationship with the Treasury, the company needed a president who belonged to the political party in office. For instance, Amos Salvador was appointed as president of the company twice: on both occasions when his uncle, Sagasta, was elected president of the government. As the roles of president and general manager were joined in the same person, such a turnover impeded the normal day-to-day management of the business, which lacked any long-term consistency.

The isolation of the business from political influences and an increase in the level of delegation in decision making and accountability were the major objectives of the reform of 24 April 1894. The reform entailed the separation of the roles of general manager and president. From then on, the role of the president changed, leaving the management of the business to the general manager with the help of three permanent commissioners of the board. The reform established clearly the functions of the permanent commissioners, the director and the president, thereby generating long-term consistency in the way that the company was managed. This reform, however, did lead to conflicts between the members of the board not linked to the Bank of Spain and those representing this institution. In 1894, and again in 1896, minority shareholders 
Table 3 Presidents of the CAT (1887-96)

\begin{tabular}{|c|c|c|}
\hline President & Period & Reason for dismissal \\
\hline Camacho & 1 July $1887-12$ October 1887 & Loss of government trust \\
\hline Ruiz Gómez & 12 October $1887-10$ October 1888 & Died \\
\hline Amós Salvador & 10 October $1888-27$ October 1890 & $\begin{array}{l}\text { Change of government, } \\
\text { July } 1890\end{array}$ \\
\hline Vida y Palacio & 27 October $1890-13$ December 1890 & Died \\
\hline $\begin{array}{l}\text { Vizconde Campo } \\
\text { Grande }\end{array}$ & 13 December $1890-11$ December 1892 & $\begin{array}{l}\text { Change of government, } \\
\text { December } 1892\end{array}$ \\
\hline Amós Salvador & 16 December 1892-3 March 1894 & $\begin{array}{l}\text { Appointed Treasury } \\
\text { minister }\end{array}$ \\
\hline González & 27 July 1894-27 June 1895 & $\begin{array}{l}\text { Change of government, } \\
\text { March } 1895\end{array}$ \\
\hline $\begin{array}{l}\text { García } \\
\text { Barzanallana }\end{array}$ & 10 July 1895-19 December 1895 & $\begin{array}{l}\text { Appointed Governor of } \\
\text { the Bank of Spain }\end{array}$ \\
\hline Sánchez Bustillo & 3 January 1896-29 September 1897 & $\begin{array}{l}\text { Change of government, } \\
\text { October } 1897\end{array}$ \\
\hline
\end{tabular}

pursued an extension of the company's mission and length both tied to the leasing contract. However, the Bank impeded these reforms, arguing that these extensions would cause an increase in risk (legajo 954, AHBE).

Changes in corporate reporting practices can be related to the importance of uncertainty. However, it extends the notion of uncertainty, as disclosure practices did not change immediately after the initial difficulties were overcome. The perception of uncertainty appears to have been affected by the internal conflicts with the two major agents: the state and the Bank of Spain. Once these conflicts were solved, in one way or another, corporate reporting changed, reducing dramatically the level of disclosure.

\section{Discussion and conclusions}

Accounting research assumes that the separation between ownership and control lies at the heart of the emergence of corporate reporting. The nineteenth century, by being characterized by both the existence of low regulatory requirements and the emergence of modern corporations, has received a great deal of attention in corporate reporting research. However, research has focused on the Anglo-Saxon context, which appears to have been characterized by peculiarities such as the predominance of stock markets as fund providers and the existence of higher levels of competition. This paper adds evidence of a very different context and of a somewhat different problem: the case of a privatization. Privatization results in higher incentives to control due to two main reasons: owners of private firms are residual claimants and they can exert a certain influence on managers either directly, if they accumulate enough control rights, or indirectly, selling their shares on the stock market. Managers will become accountable to owners and accounting information represents a basic means of assuring that they behave according to the owners' interests. 
The privatization of the tobacco monopoly implied significant changes in accountability. Under public management the responsibility of managers was restricted to assuring the legal use of public resources. Public managers were not aware of the profitability of the industry, as distribution, manufacturing and raw material acquisition were managed by different departments, simultaneously developing other activities. Additionally, political instability and the subsequent high turnover of head officers under public administration presented serious difficulties to an efficient management of the industry. Inconsistency of norms has been outlined as being important in explaining the separation between decision making and action (Brunsson and Meyer, 1990). Privatization meant the consideration of the business as a whole and the definition of clear boundaries.

Additionally, the company was subject to a double tutelage. On the one hand, managers were accountable to shareholders, among which the Bank of Spain was the most important. On the other hand, they were also accountable to the government which placed a delegate inside the company with access to all the accounting information and who could exert a veto on any decision made by the company that could threaten the state's interests.

The main conclusions of this paper refer to two different but related issues. First, accounting played a central role both in enhancing and changing the nature of accountability. The shift from public to private management led to a different form of accountability which focused on financial and managerial aspects, abandoning the former legal character. In this sense, accounting also facilitated the definition of clear boundaries within the firm (Espelan and Hirsch, 1990), framing the three basic activities that comprised till then the public tobacco monopoly. Finally, another major role that might be distinguished is the use of accounting information to project an image that the firm was being managed in an honest and efficient manner. From the time of its creation, CAT was concerned to renegotiate some of the clauses of its leasing contract, and it was considered that accounting information could be used to develop closer relationships with the state, and thereby help the company to achieve this goal.

On the other hand, several determinants of accounting disclosure can be outlined. First, and according to theoretical predictions, changes in ownership derived from privatization influenced the emergence of corporate reporting. However, the research provides support for the idea that corporate reporting did not change in a cause-effect manner, because of the change in the ownership structure. Whereas the emergence of financial reporting can be linked to the change in ownership that followed the privatization, the changes experienced by the annual reports during the period under study clearly indicate the need to seek other factors that might contribute to determine its nature.

The losses experienced by CAT in the first three years after privatization and the subsequent need to ensure market capital, and satisfy the needs of public regulators and shareholders could provide additional insights. However, the role of market capital monitoring appears to be less than expected, due mainly to the composition of the company's capital. The important role of the Bank of Spain 
as fund provider through debt, and the stability of the firm's capital softened the capital market influence. The role of capital markets is considerably less important in countries where financial institutions hold long-term relationships with firms, as is the case in most countries of Continental Europe. In this case, financial institutions may have seats on the board of directors that allow them to directly control management (Preveezer and Ricketts, 1994). Monitoring and control costs will be lowered in such a context and it follows that the need for publishing financial information will also be softened.

The conditions established by the lease contract and the subsequent strategies implemented by the firm, strongly influenced both the scale and the content of corporate reporting. The company tended to offer very detailed information while it was seeking to obtain more favourable contractual conditions. Institutional and contextual factors can be joined in a single variable: the level of uncertainty the company had to face, which appears as one of the major determinants of accounting disclosure (Sengupta, 1998).

\section{Acknowledgements}

This research has been funded by CICYT research grants (SEC 98-0282 and SEC 01-0890). I am grateful to Salvador Carmona for his many comments and suggestions. I also wish to thank participants at the VIIth Workshop on Contabilidad y Control de Gestión, Memorial Raymond Konopka, Seville, 2000, at the 23rd Annual Conference of the EAA, Munich, 2000, and at the 8th World Congress of Accounting Historians, Madrid, 2000 for their many helpful comments and insights.

\section{Notes}

1 This six-year period witnessed a dethronement, a provisional regime, a regency, a democratic monarchy, an abdication, a unitary republic, a federal republic, a coup d'état and, finally, the restoration of the Bourbon dynasty. Eighteen different governments over the period spanning 1868 to 1874 tried to re-establish order in a context that became aggravated by a revolution in Cuba and two simultaneous civil wars (Comellas, 1996). 2 Tobacco income represented on average 12.5 per cent of total ordinary income in the nineteenth century (López Linaje and Hernández Andreu, 1990).

3 The contract included the possibility of the state obtaining a loan from the company (article 19). The amount of this loan was fixed at 8 million pesetas per remaining year of the contract which meant that, at the time of the concession, the state could claim a loan of 96 million of pesetas. Additionally the contract required the lessee to deposit a fee (20 million pesetas). Loan, fee and minimum rental (90 million pesetas) represented a considerable initial investment. Moreover, the lessee additionally had to acquire the existing inventories of raw materials and stored products, which amount, though subject to a bargaining process, to around 50.9 million pesetas (AHBE, Sec. 789). Putting all these figures together the investment could amount to 257 million pesetas, an amount that should be added to the resources needed to run the daily operations.

4 The relationship between management and cigar rollers has been extensively studied (see Valdés, 1989; Baena, 1993; Gálvez Muñoz, 1997). Flexibility has been pointed to as a characteristic of pre-industrial organizations (e.g. Jaffe, 1991; McBride, 1992). In the tobacco monopoly, flexibility in work attendance and timetables appeared linked to the incorporation of women into the factories during the early decades of the nineteenth 
century. This flexibility allowed women to attend simultaneously to domestic duties and their job, while piece-rate salaries and the existence of an abundant highly skilled and socialized workforce relaxed the importance for management to control for time.

5 An example can be seen in the practice adopted by many companies from the midnineteenth century of placing important politicians on their board of directors, giving them a generous number of shares and economic benefits in exchange for their political influence. Subsidies, administrative concessions and access to information were the major returns companies expected to obtain (Milán, 2001: 401).

6 Conflicts arose in seven main areas: fees, valuation of the products the company should acquire from the State, the never ending bureaucratic procedures imposed by the Treasury Ministry, the reform of the leasing contract, taxes, and costs to be accepted by the Treasury as reducing the sales revenues (Comín and Martin Aceña, 1999: 107-10).

\section{References}

\section{Primary sources}

Historical Archives of the Tobacco Company, Seville (AHFTS)

Annual Reports of the Compañía Arrendataria de Tabacos, 1887/88 through $1895 / 96$.

Estadísticas de la Compañía Arrendataria de Tabacos.

\section{Historical Archives of the Bank of Spain, Madrid (AHBE)}

Legajo 789, Secretaría.

Legajo 954, Operaciones.

Contrato de Arrendamiento, legajo 1, e-22310.

Estatutos de la CAT, legajo 1, e-22310.

\section{Secondary sources}

Agrawal, A. and Mandelker, G.N. (1990) 'Large shareholders and the monitoring of managers: the case of antitakeover charter amendments', fournal of Financial and Quantitative Analysis, 25(2): 143-61.

Alonso Álvarez, L. (1996) 'Las estrategias empresariales de los Monopolios Españoles: de la gestión pública a la gestión privada en el Estanco del Tabaco, 1887-1936' in Comín, F. and Martín Aceña, P. (eds) La empresa publica en la historia de Espa a, Madrid: Colección Civitas.

Annisette, M. and Macías, M. (2002) 'The Bank of the state and the state of the bank. annual account of the Banco de España 1874-1896', European Accounting Reviem, forthcoming.

Baena, E. (1993) Las Cigarreras Sevillanas: un Mito en Declive (1887-1923), Atenea, Universidad de Málaga.

Berle, A.A. and Means, G.C. (1932) The Modern Corporation and Private Property, New York: Macmillan.

Bös, D. (1991) Privatization. A Theoretical Treatment, Oxford: Clarendon Press. 
Bradbury, M. (1992) 'Voluntary disclosure of financial segment data: New Zealand evidence', Accounting and Finance, 32: 15-26.

Brunsson, N. and Meyer, J.W. (1990) 'Deciding for responsibility and legitimation: alternative interpretations of organizational decision-making; sources and effects of decisions: a comment on Brunsson', Accounting, Organizations and Society, 15(1/2): 47-65.

Bryer, R.A. (1993) 'The late nineteenth-century revolution in financial reporting: accounting for the rise of investor or managerial capitalism?', Accounting, Organizations and Society, 18(7/8): 649-90.

Carmona, S. and Macías, M. (2001) 'Institutional pressures, monopolistic conditions and the implementation of early cost accounting practices. The case of the Royal Tobacco Factory of Seville, 1820-1887', Abacus, 37(2): 139-65.

Chow, C.W. (1982) 'The impacts of accounting regulation on bondholder and shareholder wealth: the case of Securities Acts', The Accounting Reviem, LVIII(3): 485-520.

Comellas, J.L. (1996) Historia de Espa a Contemporánea, Madrid: Ediciones Rialp.

Comín, F. (1997) Historia de la Hacienda Pública, II. Espa a (1808-1995), Barcelona: Crítica Grijalbo.

Comín, F. and Martín Ace a, P. (1999) Tabacalera y el Estanco del Tabaco en Espa a (1636-1998), Madrid: Fundación Tabacalera.

Cruz Valenciano, J. (1996) Gentlemen, Bourgeois, and Revolutionaries: Political Change and Cultural Persistence Among the Spanish Dominant Groups, 1750-1850, Cambridge: Cambridge University Press.

Cruz Valenciano, J. (2000) Los Notables de Madrid. Las Bases Sociales de la Revolución Liberal Espa ola, Madrid: Alianza Editorial.

Delgado, E. (1896) 'La Compañía Arrendataria de Tabacos', in Santías, A. and de Figueroa, G. (eds) Anuario de la Renta de Tabacos de Espa a para los empleados de la Compa ía Arrendataria, Madrid: Tipografia M. Gines.

Demsetz, H. (1995) The Economics of the Business Firm, Cambridge: Cambridge University Press.

Dhaliwal, D.S. (1980) 'The effect of the firm's capital structure on the choice of accounting methods', The Accounting Reviem, Jan.: 78-84.

Edwards, J.R. (1992) 'Companies, corporations and accounting change, 1835-1933: a comparative study', Accounting E Business Research, 23: 59-73.

Edwards, J.R., Anderson, M. and Matthews, D. (1997) 'Accountability in a free-market economy: the British company audit, 1866', Abacus, 33: 1-25.

Espelan, W.N. and Hirsch, P.M. (1990) 'Ownership changes, accounting practices and the redefinition of the corporation', Accounting, Organizations and Society, 15(1/2): 77-96.

Fama, E.F. (1980) 'Agency problem and the theory of the firm', Fournal of Political Economy, 88(2): 288-307.

Fama, E.G. and Jensen, M.C. (1983) 'Separation of ownership and control', Journal of Lam and Economics, 26: 301-26.

Fuente, G. de la (2000) Los revolucionarios de 1868. Elites y Poder en la Espa a Liberal, Madrid: Marcial Pons Historia. 
Fusi, J.P. and Palafox, J. (1997) Espa a: 1808-1996. El Desafio de la Modernidad, Madrid: Ensayo y Pensamiento Espasa.

Gálvez Mu oz, L. (1997) 'Breadwinning patterns and family exogenous factors: workers at the tobacco factory of Seville during the industrialization process (1887-1945)', International Review of Social History, 42 (Supp.5): $87-128$.

Hernández Esteve, E. (1995). 'A review of recent Spanish publications in accounting, business and financial history', Accounting Business E Financial History, 5(2): 237-69.

Ilustre Colegio de Agentes de Cambio y Bolsa de Madrid (1981) Sintesis de la Historia de la Bolsa de Madrid, Madrid: Bolsa de Madrid.

Jaffe, J.A. (1991) 'The Struggle for Market Power. Industrial Relations in the British Coal Industry, 1800-1840' New York: Cambridge University Press.

Jarrell, G.A. and Poulsen, A.B. (1987) 'Shark repellents and stock prices. the effects of antitakeover amendments since 1980', Journal of Financial Economics, 19: $127-68$.

Jensen, M.C. (1989) 'Eclipse of the public corporation', Harvard Business Reviem, 67(5): 61-74.

Jensen, M.C. and Meckling, W.H. (1976) 'Theory of the firm: managerial behaviour, agency costs and ownership structure', Journal of Financial Economics, 3: 305-60.

Leftwich, R.W., Watts, R.L. and Zimmerman, J.L. (1981) 'Voluntary corporate disclosure: the case of interim reporting', Fournal of Accounting Research, 19 (Supp.): 50-77.

López Linaje, J. and Hernández Andreu, J. (1990) Una Historia del Tabaco en Espa a, Madrid: Ministerio de Agricultura, Pesca y Alimentación.

McBride, T. (1992) 'Women's work and industrialization', in Berlanstein, L.R. (ed.) The Industrial Revolution and Work in the Nineteenth-century Europe, London and New York: Routledge, pp. 63-80.

McKinnon, J.L. and Dalimunthe, L. (1993) 'Voluntary disclosure of segment information by Australian diversified companies', Accounting and Finance, 33: 33-50.

Milán García, J.R. (2001) Sagasta o el Arte de hacer Política, Madrid: Biblioteca Nueva.

Parker, D. (1993) 'Ownership, organizational changes and performance', in Clarke, T. and Pitelis, C. (eds), The Political Economy of Privatization, London and New York: Routledge, pp. 31-53.

Prevezer, M. and Ricketts, M. (1994) 'Corporate governance: the UK compared with Germany and Japan', in Dimsdale, N. and Prevezer, M. (eds) Capital Markets and Corporate Governance, Oxford: Clarendon Press, pp. 237-56.

Ringrose, D. (1996) Espa a 1700-1900: el mito de un fracaso, Madrid: Alianza Editorial.

Santías, A. and de Figueroa, G. (1900) Anuario de la Renta de Tabacos en Espa a para los empleados de la Compa ía Arrendataria, Madrid: CAT. 
Sengupta, P. (1998) 'Corporate disclosure quality and the cost of debt', The Accounting Reviem, 73(4): 459-74.

Shleifer, A. and Vishny, R. (1986) 'Large shareholders and corporate control', Fournal of Political Economy, 94(3): 461-88.

Sociedad Rectora de la Bolsa de Valores de Madrid (1993) Bolsa de Madrid: 100 a os de Historia, Madrid: SRBVM.

Stiglitz, J.E. (1989) The Economic Role of the State, Oxford: Basil Blackwell. Stiglitz, J.E. (1988) La Economía del Sector Público, Barcelona: Antoni Bosch. Storrar, A.C. and Pratt, K.C. (2000) 'Accountability vs. privacy, 1844-1907: the coming of the private company', Accounting Business E Financial History, 10(3): 259-91.

Tejerizo López, J.M. (1975) Los Monopolios Fiscales, Madrid: Instituto de Estudios Fiscales.

Toms, J.S. (1998) 'The supply and demand for accounting information in an unregulated market: examples from the Lancashire cotton mills, 1855-1914', Accounting, Organizations and Society, 23(2): 217-38.

Torres Villanueva, E. (1998) La Fundación de la Compa ía Arrendataria de Tabacos, Documento de trabajo no. 9808, Madrid: Fundación Empresa Pública.

Tortella, G. (1995) El desarrollo de la Espa a Contemporánes. Historia Económica de los siglos $X I X$ y $X X$, Madrid: Alianza Universidad Textos.

Valdés, C. (1989) La Fábrica de Tabacos de Alicante, Alicante: CAM.

Vickers, J. and Yarrow, G. (1988) Privatisation: An Economic Analysis, Cambridge, MA: MIT Press.

Watts, R.L. (1977) 'Corporate financial statements, a product of the market and political processes', Australian fournal of Management, 2: 53-75.

Wright, M. and Thompson, S. (1994) 'Divestiture of public sector assets', in Jackson, P.M. and Price, C.M. (eds), Privatisation and Regulation. A Reviem of the Issues, London: Longman, pp. 35-76.

Zeckhauser, R.J. and Horn, M. (1989) 'The control and performance of state owned enterprises' in MacAvoy, P.W., Stanbury, W.T., Yarrow, G. and Zeckhauser, R.J. (eds), Privatization and State Omned Enterprises: Lessons from the United States, Great Britain and Canada, Boston, MA: Kluwer, pp. 7-57. 